\title{
PENGARUH CAR,NPL DAN LDR TERHADAP RETURN ON ASSET PADA BANK UMUM KONVENSIONAL YANG TERDAFTAR DI BEI PERIODE 2015-2019
}

\author{
Yuslinda Nasution \\ Dosen Tetap Program S1 Juusan Manajemen Fakultas Ekonomi Universitas Satya Negara Indonesia \\ Email : n.yuslinda@yahoo..com
}

ABSTRAK

Penelitian ini bertujuan untuk mengetahui pengaruh Capital Adequacy Ratio (CAR), Non Performing Loan (NPL), dan Loan to Deposit Ratio (LDR) terhadap Return On Assets (ROA) pada Bank Umum Konvensional yang terdaftar di Bursa Efek Indonesia Periode 20152019.Populasi dalam penelitian ini adalah Bank-Bank yang terdaftar di Bursa Efek Indonesia. Teknik pengambilan sampling yang digunakan adalah purposive random sampling. Sampel penelitian ini adalah

61 Bank yang terdaftar di Bursa Efek Indonesia periode 2015-2019. Teknik analisis data yang digunakan dalam penelitian ini adalah analisis regresi berganda. Hasil penelitian secara parsial menunjukan bahwa Loan to Deposit Ratio (LDR) tidak berpengaruh terhadap Return On Assets (ROA). Capital Adequacy Ratio (CAR) dan Non Performing Loan (NPL) berpengaruh terhadap Return On Assets (ROA). Sedangkan secara simultan Capital Adequacy Ratio (CAR), Non Performing Loan (NPL) dan Loan to Deposit Ratio (LDR) berpengaruh terhadap Return On Assets (ROA).

\section{Kata Kunci : ROA, CAR,NPL,LDR}

\section{PENDAHULUAN}

Perkembangan ekonomi di Indonesia pada saat ini bisa dikatakan cukup baik, dimana masyarakat sudah mulai mengenal dan menjadi pengguna dari lembaga keuangan maupun lembaga non keuangan untuk melakukan berbagai transaksi yang berkaitan dengan dana maupun yang lainnya. Salah satu lembaga keuangan yang saat ini berkembang cukup pesat di Indonesia adalah bank. Bank adalah lembaga keuangan yang kegiatan utamanya adalah menghimpun dana dari masyarakat dan menyalurkannya kembali dana tersebut ke masyarakat serta memberikan jasa Bank lainnya (Kasmir $2016: 3$ ).

Profitabilitas dapat dikatakan sebagai salah satu indikator yang paling penting dalam mengukur kinerja keuangan bank. Profitabilitas digunakan untuk mengukur efektivitas perusahaan di dalam menghasilkan keuntungan dengan memanfaatkan aktiva yang di milikinya. Semakin besar profitabilitas menunjukan kinerja perusahaan semakin baik, karena tingkat pengembalian semakin besar, rasio ini sekaligus merupakan indikator efisiensi manajerial bank yang mengindikasikan kemampuan manajerial dalam mengelola aset untuk memperoleh keuntungan.

Tabel 1.1

Data ROA Bank Konvensional

\begin{tabular}{|l|c|c|c|}
\hline \multirow{2}{*}{ Kode } & \multicolumn{3}{|c|}{ Return On Asset } \\
\cline { 2 - 4 } & 2017 & 2018 & 2019 \\
\hline BJBR & $2,01 \%$ & $1,71 \%$ & $1,68 \%$ \\
\hline BBMD & $3,19 \%$ & $2,96 \%$ & $2,72 \%$ \\
\hline BTPN & $3,06 \%$ & $1,84 \%$ & $1,29 \%$ \\
\hline ARTOS & $-1,04 \%$ & $-2,76 \%$ & $-15,89 \%$ \\
\hline BSIM & $1,26 \%$ & $0,25 \%$ & $0,23 \%$ \\
\hline
\end{tabular}

Sumber: Data Diolah Penulis 
Data di atas merupakan data penurunan Return On Assets di beberapa bank konvensional. Penurunan atau kenaikan Return On Assets secara teoritis dan didukung oleh beberapa hasil penelitian ternyata dapat di sebabkan oleh beberapa faktor. Faktor yang di anggap mampu mempengaruhi Return on Asset (ROA) diantaranya Capital Adequacy ratio ( CAR), Non Performing Loan ( NPL), Loan to Deposit Ratio (LDR).

Capital Adequacy Ratio (CAR) sering disebut dengan istilah rasio kecukupan modal bank, yaitu bagaimana sebuah bank mampu membiayai aktivitas kegiatannya dengan kepemilikan modal yang dimilikinya ( Irham Fahmi, 2015:153)

Terkait dengan teori sinyal, pengaruh Capital Adequacy ratio (CAR) terhadap Return on Assets (ROA) adalah Capital Adequacy ratio (CAR) dapat memberi sinyal good news bagi pengguna laporan keuangan apabila rasio Capital Adequacy ratio (CAR) sesuai atau lebih besar dari ketentuan yang telah ditetapkan. Hal tersebut menunjukan bahwa semakin besar Capital Adequacy ratio (CAR) maka keuntungan Return on Assets (ROA) yang diperoleh perusahaan semakin besar dan kinerja perusahaan mengalami peningkatan. Capital Adequacy ratio (CAR) juga dapat memberi sinyal bad news bagi pengguna laporan keuangan apabila rasio Capital Adequacy ratio (CAR) kurang dari ketentuan yang telah ditetapkan. Hal tersebut menunjukan bahwa semakin kecil Capital Adequacy ratio (CAR) maka keuntungan Return on Assets (ROA) yang diperoleh perusahaan semakin rendah dan kinerja perusahaan menurun.

Non Performing Loan (NPL) adalah salah satu rasio yang digunakan untuk mengukur resiko kredit yang diberikan bank kepada pihak debitur. Semakin tinggi rasio maka akan semakin buruk kualitas kredit bank yang menyebabkan jumlah kredit bermasalah semakin besar, dan oleh karena itu bank harus menanggung kerugian dalam kegiatan operasionalnya sehingga berpengaruh terhadap penurunan laba atau Return on Assets (ROA) yang diperoleh bank (Kasmir, 2013: 115). Semakin tinggi Non Performing Loan (NPL) maka akan semakin buruk kualitas kredit bank yang menyebabkan jumlah kredit bermasalah semakin besar dan menyebabkan kerugian, sebaliknya jika semakin rendah Non Performing Loan (NPL) maka laba atau Return on Assets ( ROA) bank tersebut akan semakin meningkat.

Loan to Deposit Ratio (LDR) adalah rasio yang digunakan untuk mengukur komposisi jumlak kredit yang diberikan dibandingkan dengan jumlah dana masyarakat dan modal sendiri yang digunakan (Kasmir,2014:225). Loan to Deposit Ratio (LDR) memiliki pengaruh positif terhadap perubahan laba atau Return On Assets (ROA) artinya jika Loan to Deposit Ratio (LDR) menunjukan angka yang tinggi maka perubahan laba atau Return On Assets (ROA) juga tinggi dan sebaliknya, hal ini dapat dimaknai bahwa jika Loan to Deposit Ratio (LDR) menunjukan angka yang rendah maka bank kehilangan kesempatan untuk memperoleh laba atau Return On Assets (ROA) yang lebih besar.

Tetapi pada kenyataannya tidak selamanya variabel-variabel di atas mampu mempengaruhi Return On Assets (ROA), data berikut ini menunjukan hubungan yang tidak sesuai teori antara variabel Return On Assets (ROA) dan variabel lainnya.

Tabel 1.2

Data Rasio Bank konvensional

\begin{tabular}{|c|c|c|c|c|c|c|}
\hline \multirow{2}{*}{ Nama bank } & \multirow{2}{*}{ Rasio } & \multicolumn{5}{|c|}{ Tahun } \\
\hline & & 2015 & 2016 & 2017 & 2018 & 2019 \\
\hline \multirow{4}{*}{\begin{tabular}{|l|} 
Bank \\
Pembangunan \\
Daerah Jawa \\
Barat dan \\
Banten (BJBR)
\end{tabular}} & Return On Assets & $2,04 \%$ & $2,22 \%$ & $2,01 \%$ & $1,71 \%$ & $1,68 \%$ \\
\hline & Capital Adequacy Ratio & $16,21 \%$ & $18,43 \%$ & $18,77 \%$ & $18,63 \%$ & $17,71 \%$ \\
\hline & Non Performing Loan & $2,91 \%$ & $1,69 \%$ & $1,51 \%$ & $1,65 \%$ & $1,58 \%$ \\
\hline & Loan to Deposit Ratio & $88,13 \%$ & $86,7 \%$ & $87,27 \%$ & $91,89 \%$ & $97.89 \%$ \\
\hline
\end{tabular}




\begin{tabular}{|c|l|c|c|c|c|c|}
\hline \multirow{3}{*}{$\begin{array}{c}\text { Bank Mestika } \\
\text { Dharma } \\
\text { (BBMD) }\end{array}$} & Return On Assets & $3,53 \%$ & $2,30 \%$ & $3,19 \%$ & $2,96 \%$ & $2,72 \%$ \\
\cline { 2 - 7 } & Capital Adequacy Ratio & $28,26 \%$ & $35,12 \%$ & $34,68 \%$ & $34,58 \%$ & $38,60 \%$ \\
\cline { 2 - 7 } Non Performing Loan & $2,26 \%$ & $3,59 \%$ & $2,58 \%$ & $2,33 \%$ & $2,26 \%$ \\
\cline { 2 - 7 } & Loan to Deposit Ratio & $101,61 \%$ & $80,93 \%$ & $81,02 \%$ & $86,93 \%$ & $88,06 \%$ \\
\hline
\end{tabular}

Sumber : Data Diolah Peneliti

Pada Bank Pembangunan Daerah Jawa Barat dan Banten tahun 2016 dan 2017 Capital Adequacy Ratio (CAR) mengalami kenaikan sebesar 0,34\% sedangkan Return On Assets (ROA) mengalami penurunan sebesar $0,21 \%$. Kondisi ini tidak sesuai teori seharusnya pada saat Capital Adequacy Ratio (CAR) naik, Return On Assets ( ROA) seharusnya mengalami peningkatan. Pada tahun 2016 dan 2017 Non Performing Loan (NPL) mengalami penurunan sebesar 0,18\% sedangkan Return On Assets (ROA) mengalami penurunan sebesar 0,21\%. Kondisi ini tidak sesuai teori seharusnya pada saat Non Performing Loan (NPL) turun, Return On Assets (ROA) seharusnya akan mengalami peningkatan. Pada tahun 2016 dan 2017 Loan to Deposit Ratio (LDR) mengalami kenaikan sebesar $0,57 \%$ sedangkan Return On Assets (ROA) mengalami penurunan sebesar $0,21 \%$. Kondisi ini tidak sesuai dengan teori., seharusnya pada saat Loan to Deposit Ratio (LDR) turun, Return On Assets (ROA) seharusnya akan mengalami penurunan.

Pada Bank Mestika Dharma tahun 2016 dan 2017 Capital Adequacy Ratio (CAR) mengalami penurunan sebesar 0,44\% sedangkan Return On Assets (ROA) mengalami kenaikan sebesar $0,89 \%$. Kondisi ini tidak sesuai teori seharusnya pada saat Capital A(ROA) seharusnya mengalami penurunan. Pada tahun 2017 dan 2018 Non Performing Loan (NPL) mengalami penurunan sebesar 0,25\% sedangkan Return On Assets (ROA) mengalami penurunan sebesar $0,23 \%$. Kondisi ini tidak sesuai teori seharusnya pada saat Non Performing Loan (NPL) turun, Return On Assets (ROA) seharusnya akan mengalami peningkatan. Pada tahun 2017 dan 2018 Loan to Deposit Ratio (LDR) mengalami kenaikan sebesar 5,91\% sedangkan Return On Assets (ROA) mengalami penurunan sebesar $0,23 \%$. Kondisi ini tidak sesuai dengan teori, seharusnya pada saat Loan to Deposit Ratio (LDR) naik, Return On Assets (ROA) seharusnya akan mengalami peningkatan.

Tabel 1.3 Research Gap

\begin{tabular}{|c|c|c|c|}
\hline Varibel & Nama Peneliti & Tahun & Hasil Penelitian \\
\hline \multirow[t]{3}{*}{ CAR } & Aminar Sutra Dewi & 2017 & $\begin{array}{l}\text { CAR tidak berpengaruh } \\
\text { terhadap ROA }\end{array}$ \\
\hline & $\begin{array}{l}\text { Erric Wijaya, Aulia wahyuning } \\
\text { tiyas }\end{array}$ & 2016 & $\begin{array}{l}\text { CAR Tidak berpengaruh } \\
\text { terhadap ROA }\end{array}$ \\
\hline & $\begin{array}{l}\text { Daniel Nugroho, Marjam } \\
\text { Mangantar, Joy E.Tulung }\end{array}$ & 2019 & $\begin{array}{l}\text { CAR berpengaruh terhadap } \\
\text { ROA }\end{array}$ \\
\hline \multirow[t]{3}{*}{ NPL } & Aminar Sutra Dewi & 2017 & $\begin{array}{l}\text { NPL berpengaruh } \\
\text { terhadap ROA }\end{array}$ \\
\hline & $\begin{array}{l}\text { Putu Intan Trisna Dewi, } \\
\text { Ketut Suryanawa }\end{array}$ & 2018 & $\begin{array}{l}\text { NPL berpengaruh } \\
\text { terhadap ROA }\end{array}$ \\
\hline & \begin{tabular}{|l} 
Daniel Nugroho, Marjam \\
Mangantar, Joy E.Tulung
\end{tabular} & 2019 & $\begin{array}{l}\text { NPL tidak berpengaruh } \\
\text { terhadap ROA }\end{array}$ \\
\hline \multirow[t]{3}{*}{ LDR } & Aminar sutra dewi & 2017 & $\begin{array}{l}\text { LDR berpengrauh } \\
\text { terhadap ROA }\end{array}$ \\
\hline & $\begin{array}{l}\text { Erric Wijaya, Aulia } \\
\text { Wahyuningtiyas (2016) }\end{array}$ & 2016 & $\begin{array}{l}\text { LDR tidak berpengaruh } \\
\text { terhadap ROA }\end{array}$ \\
\hline & $\begin{array}{l}\text { Putu Intan Trisna Dewi, } \\
\text { Ketut Suryanawa }\end{array}$ & 2018 & $\begin{array}{l}\text { LDR berpengaruh } \\
\text { terhadap ROA }\end{array}$ \\
\hline
\end{tabular}

Sumber: Data Diolah Peneliti 
Berdasarkan Research Gep terdapat pada tabel diatas dapat dijelaskan sebagai berikut:

1. Capital Adequancy Ratio ( CAR) dalam peneli Aminar sutra dewi 2017, Erric wijaya, Aulia wahyuning tiyas 2016 menunjukan bahwa tidak adanya pengaruh signifikan terhadap Return On Assets (ROA), sedangkan penelitian yang dilakukan Daniel nugroho, Marjam mangantar, Joy E.Tulung 2019 menunjukan bahwa Capital Adequancy Ratio (CAR) berpengaruh signifikan terhadap Return On Assets (ROA).

2. Non Performing Loan (NPL) dalam penelitian Daniel nugroho, Marjam mangantar, Joy E.Tulung 2019 menunjukan bahwa tidak adanya pengaruh signifikan terhadap Return On Assets (ROA)., sedangkan penelitian yang dilakukan oleh Aminar sutra dewi 2017, Putu intan trisna dewi, Ketut suryanawa 2018 menunjukan bahwa Non Performing Loan (NPL) berpengaruh signifikan terhadap Return On Assets (ROA).

3. Loan to Deposit Ratio ( LDR) dalam penelitian Erric wijaya, Aulia wahyuning tiyas 2016, menunjukan bahwa tidak adanya pengaruh signifikan terhadap Return On Assets (ROA), sedangkan penelitian yang dilakukan oleh Aminar sutra dewi 2017, Putu intan trisna dewi, Ketut suryanawa 2018 menunjukan bahwa Loan to Deposit Ratio ( LDR) berpengaruh signifikan terhadap Return On Assets (ROA).

Berdasarkan fenomena dan masih adanya perbedaan hasil penelitian sebelumnya peneliti tertarik dan ingin melakukan penelitian dengan mengambil judul "Pengaruh Capital Adequacy Ratio (CAR), Net Performing Loan (NPL), Loan to Deposit Ratio ( LDR) terhadap Return On Assets (ROA) pada Bank Umum Konvensional yang Terdaftar di BEI Periode 20152019".

Adapun kerangka pemikiran dalam penelitian ini adalah sebagai berikut :

Gambar 3.1

Kerangka Pemikiran

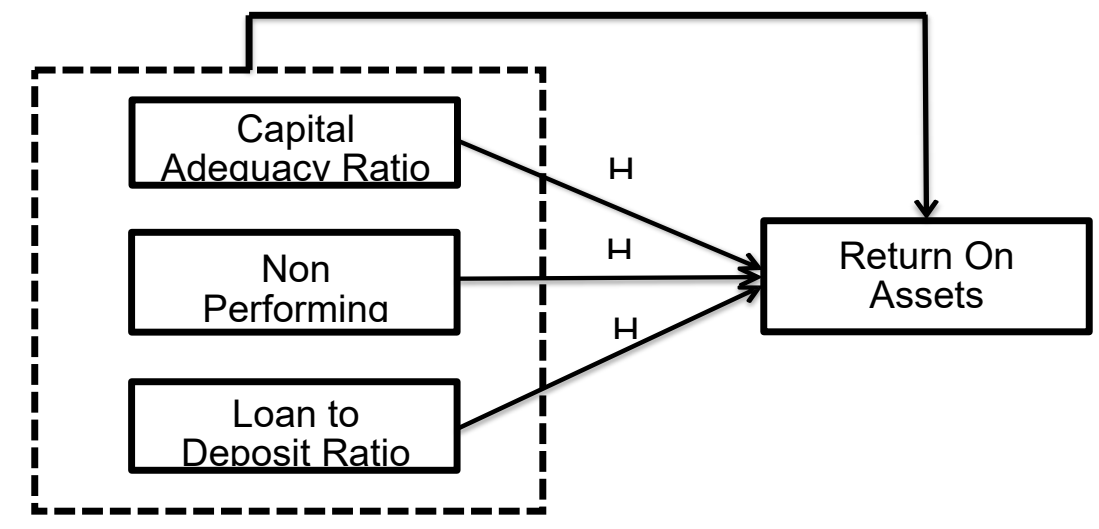

( Sumber : data yang diolah peneliti 2020)

ROA adalah rasio yang digunakan untuk mengukur kemampuan bank dalam menghasilkan keuntungan secara relatif dibandingkan dengan total asetnya serta mengukur kemampuan perusahaan menghasilkan laba bersih berdasarkan tingkat aset. Semakin besar nilai rasio ROA semakin besar pula tingkat keuntungan yang dicapai bank.

Menurut Irham Fahmi (2015:137) ROA merupakan rasio yang digunakan untuk mengukur profitabilitas perusahaan. Return on Asset (ROA) disebut juga dengan laba atas asset. Berikut faktor yang mempengaruhi (ROA) yaitu:

1. Capital Adequacy Ratio (CAR) 
.CAR adalah rasio yang memperlihatkan seberapa jauh seluruh aktiva bank yang mengandung rasio yang memperlihatkan seberapa jauh seluruh aktiva bank yang mengandung risiko (kredit, penyertaan surat berharga, tagihan pada bank lain) ikut dibiayai dari dana modal sendiri bank disamping memperoleh dana-dana dari sumber-sumber diluar bank, seperti dana masyarakat, pinjaman (utang), dan lain-lain.

\section{Non Performing Loan ( NPL)}

NPL mencerminkan risiko kredit, semakin kecil NPL semakin pula risiko kredit yang ditanggung oleh bank.

\section{Loan to Deposit Ratio ( LDR)}

LDR merupakan rasio yang menyatakan seberapa jauh bank telah menggunakan uang para penyimpan (depositor) untuk memberikan pinjaman adalah uang yang berasal dari titipan para penyimpan.

\section{Pengertian Capital Adequacy Ratio (CAR )}

Menurut kasmir (2016:46) Capital Adequacy ratio (CAR) adalah rasio kinerja bank untuk mengukur kecukupan modal yang dimiliki bank untuk menunjang aktiva yang mengandung atau menghasilkan risiko, seperti kredit yang diberikan kepada nasabah. Semakin besar Capital Adequacy Ratio (CAR) makan keuntungan bank juga semakin besar. Dengan kata lain, semakin kecil risiko suatu bank semakin besar keuntungan yang diperoleh bank.

\section{Pengertian Non Performing Loan (NPL)}

Menurut Dewa (2015:109) Non Performing Loan (NPL) gross merupakan perbandingan antara kredit macet dengan total kredit yang disalurkan oleh bank. NPL gross tidak memperhitungkan cadangan atas kredit macet. Semakin tinggi rasio ini mengindikasikan rendahnya $\mathrm{k}$ ualitas proses penyaluran pembiayaan yang dijalankan oleh bank.

\section{Pengertian Loan To Deposit Ratio ( LDR)}

Menurut kasmir (2014:225), penilaian kesehatan likuiditas bank yang berupa Loan to Deposit Ratio (LDR) merupakan total jumlah kredit yang dibagikan (disalurkan) dengan total dana simpanan pihak ke III.

\section{HIPOTESIS}

\section{Hipotesis secara parsial}

$\mathrm{H}_{01}: \beta 0$ Tidak terdapat pengaruh variabel CAR terhadap ROA.

$\mathrm{H}_{\mathrm{a} 1}: \beta 0$ Terdapat pengaruh variabel CAR terhadap ROA.

$\mathrm{H}_{02}: \beta 0$ Tidak terdapat pengaruh variabel NPL terhadap ROA.

$\mathrm{H}_{\mathrm{a} 2}: \beta 0$ Terdapat pengaruh variabel NPL terhadap ROA.

$\mathrm{H}_{03}: \beta 0$ Tidak terdapat pengaruh variabel LDR terhadapROA.

$\mathrm{H}_{\mathrm{a} 3}: \beta 0$ Terdapat pengaruh variabel LDR terhadap ROA.

$\mathrm{H}_{04}: \beta 0$ Tidak terdapat pengaruh variabel CAR, NPL dan LDR terhadap ROA.

$\mathrm{H}_{\mathrm{a} 4}: \beta 0$ Terdapat pengaruh variabel CAR,NPL dan LDR terhadap ROA.

\section{Hipotesis secara simultan}

$\mathrm{H}_{04}: \beta 0$ Tidak terdapat pengaruh variabel CAR, NPL dan LDR secara simultan terhadap ROA.

$\mathrm{H}_{\mathrm{a} 4}: \beta 0$ Terdapat pengaruh variabel CAR,NPL dan LDR secara simultan terhadap ROA

\section{METODE}

\section{Populasi dan Sampel}


Populasi yang akan menjadi objek dalam penelitian ini adalah perusahaan perbankan yang terdaftar di BEI perode 2015-2019. Teknik pengambilan sampling yang digunakan adalah purposive random sampling.

\begin{tabular}{|c|c|c|c|c|}
\hline $\begin{array}{l}\text { Variabel } \\
\text { Penelitian }\end{array}$ & Definisi & Parameter & & Skala \\
\hline \multirow[t]{2}{*}{$\begin{array}{l}\text { Capital } \\
\text { Adequacy } \\
\text { Ratio }(\mathrm{CAR}= \\
\left.\mathrm{X}_{1}\right)\end{array}$} & $\begin{array}{lr}\text { Rasio } & \text { kinerja } \\
\text { bank } & \text { untuk } \\
\text { mengukur kecukupan } & \text { modal yang } \\
\text { dimiliki }\end{array}$ & $\begin{array}{l}\text { Modal } \\
\text { CAR }= \\
\text { ATMR }\end{array}$ & $\mathrm{x} 100 \%$ & Rasio \\
\hline & $\begin{array}{l}\text { bank untuk } \\
\text { menunjang aktiva } \\
\text { yang mengandung } \\
\text { atau menghasilkan } \\
\text { resiko. }\end{array}$ & & & \\
\hline $\begin{array}{l}\text { Non } \\
\text { Performing } \\
\text { Loan } \\
\left(\mathrm{NPL}=\mathrm{X}_{2}\right)\end{array}$ & $\begin{array}{l}\text { Rasio ini } \\
\text { menunjukan } \\
\text { kemampuan bank } \\
\text { dalam mengelola } \\
\text { kredit bermasalah } \\
\text { yang diberikan } \\
\text { oleh bank }\end{array}$ & 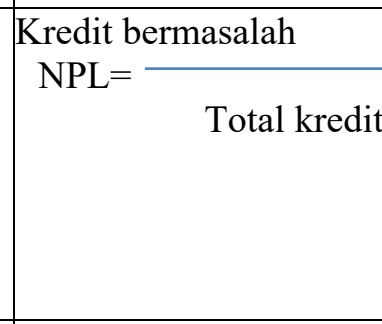 & $\mathrm{x} 100 \%$ & Rasio \\
\hline $\begin{array}{l}\text { Loan to } \\
\text { Deposit Ratio } \\
\left(\mathrm{LDR}=\mathrm{X}_{3}\right)\end{array}$ & $\begin{array}{l}\text { Rasio ini enunjukan } \\
\text { tingkat kemampuan } \\
\text { bank dalam } \\
\text { mnyalurkan dananya } \\
\text { Berasal dari } \\
\text { masyarakat dalam } \\
\text { bentuk Kredit }\end{array}$ & $\mathrm{LDR}=\frac{\text { Total kredit }}{\mathrm{DPK}}$ & $\mathrm{x} 100 \%$ & \\
\hline
\end{tabular}




\begin{tabular}{|c|c|c|c|}
\hline $\begin{array}{l}\text { Return On } \\
\text { Assets (ROA= } \\
\text { Y) }\end{array}$ & $\begin{array}{l}\text { Rasio ini digunakan } \\
\text { untuk menunjukan } \\
\text { kemampuan } \\
\text { perusahaan } \\
\text { menghasilkan } \\
\text { laba. }\end{array}$ & $\begin{array}{l}\text { Laba bersih } \\
\text { ROA }= \\
\text { Total Assets }\end{array}$ & $\mathrm{x} 100 \%$ \\
\hline
\end{tabular}

\section{Teknik Analisis Data}

\section{Uji Normalitas Residual}

Uji normalitas pada model regresi digunakan untuk menguji apakah nilai residual yang dihasilkan dari regresi terdistribusi secara normal atau tidak, yaitu dengan melihat penyebaran data pada sumber diagonal pada grafik normal P-P Plot of regression standardized residual.

\section{Uji Multikolinieritas}

Pengujian multikolinearitas bertujuan untuk menguji apakah model regresi ditemukan adanya korelasi antar variabel bebas (independen). Untuk menemukan ada atau tidaknya multikolinearitas dalam model regresi dapat diketahui dari nilai toleransi dan nilai variance inflation factor(VIF).

\section{Uji Heteroskedastisitas}

Uji hateroskedastisitas digunakan untuk menguji apakah dalam sebuah model regresi terjadi ketidaksamaan varians dari residual pada setiap pengamatan. Jika dalam varians dari residual satu pengamatan ke pengamatan lain tetap, maka disebut hateroskedastisitas dan jika berbeda disebut heteroskedastisitas.

\section{Uji Autokorelasi}

Autokorelasi merupakan karelasi antara anggota observasi yang disusun menurut waktu dan tempat. Metode pengujian menggunakan uji Durbin- Waston ( DW test). Kriteria pengujian:

- $\quad \mathrm{DU}<\mathrm{DW}<4$-DU maka $\mathrm{H}_{\mathrm{o}}$ diterima, artinya tidak terjadi autokorelasi

- $\quad$ DW $<$ DL atau DW $>4$-DL maka $\mathrm{H}_{\mathrm{o}}$ ditolak, artinya terjadiautokorelasi

- $\quad$ DL $<$ DW $<$ DU atau 4-DU $<$ DW $<4$-DL, artinya tidak ada kepastian atau kesimpulan yang pasti.

\section{Analisa Pembahasan}

\section{Analisa Deskriptif}

Analisa deskriptif bertujuan untuk memberikan gambaran atau deskripsi mengenai variabel penelitian yang terdiri dari perputaran kas $\left(\mathrm{X}_{1}\right)$, Kecukupan modal $\left(\mathrm{X}_{2}\right)$, Risiko operasi $\left(\mathrm{X}_{3}\right)$, dan profitabilitas (Y).

\section{Statistik Deskriptif Variabel Penelitian}

\begin{tabular}{|l|l|l|l|l|l|}
\hline & N & Minimum & Maximum & Mean & Std. Deviation \\
\hline ROA & 61 &, 25 & 3,50 & 1,8056 &, 83205 \\
CAR & 61 & 15,70 & 29,58 & 20,2249 & 3,11355 \\
NPL & 61 & 1,58 & 4,74 & 2,9075 & 85476 \\
LDR & 61 & 73,61 & 102,66 & 89,7649 & 5,96598 \\
Valid N (listwise) & 61 & & & & \\
\hline
\end{tabular}

Sumber: Data Diolah Dengan SPSS 
Uji Asumsi Klasik

Hasil Uji Normalitas Residual

\section{Gambar 4.1}

\section{Hasil Uji Normalitas Residual Probability Plot}

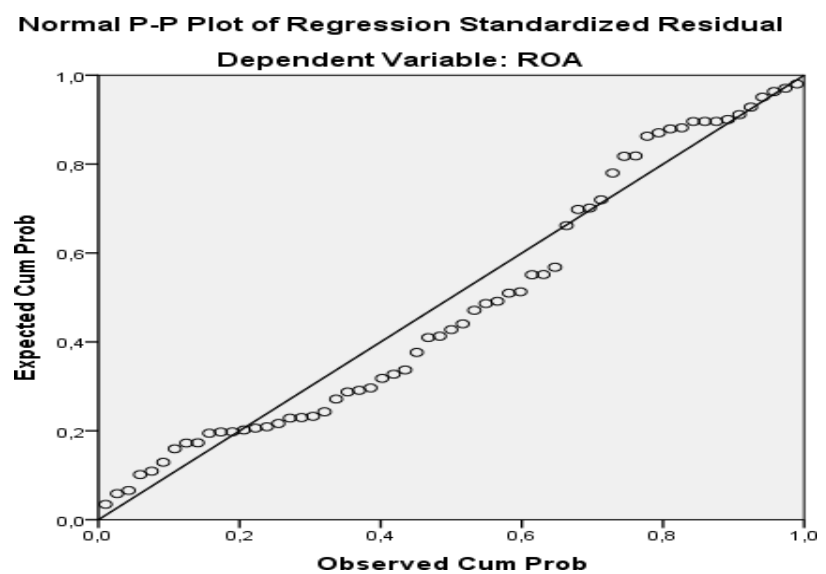

Sumber: Data Diolah Dengan SPSS

Sumber: Data Diolah Dengan SPSS

Dari gambar 4.1 grafik diatas dapat dilihat bahwa titik-titik menyebar sekitar garis dan mengikuti garis diagonal, maka nilai residual tersebut terdistribusi normal.

\section{Hasil Uji Heteroskedastisitas}

\section{Gambar 4.2}

\section{Grafik Scatterplot}

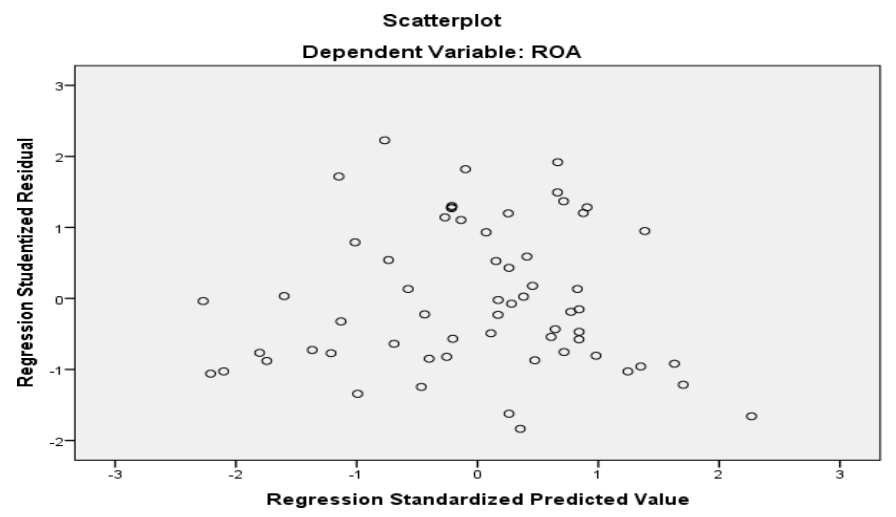

Hasil Pengujian Heteroskedastisitas pada perbankan yang terdaftar di BEI terlihat pola yang dihasilkan tidak jelas, dimana titik-titik menyebar diatas dan dibawah angka 0 pada sumbu $\mathrm{Y}$, maka ini menunjukan titik tidak terjadi Heteroskedastisitas

\section{Hasil Uji Autokolerasi}




\begin{tabular}{|c|c|c|}
\hline Model & $\mathrm{R}$ & Durbin-Watson \\
\hline & $428^{\mathrm{a}}$ & 1,394 \\
\hline
\end{tabular}

Sumber: Data Diolah Dengan SPSS

Berdasarkan table 4.5 di atas, diketahui nilai DW 1,394 nilai ini lebih dari satu atau kurang dari tiga, maka dapat disimpulkan bahwa model regresi dalam penelitian tidak terjadi autokorelasi.

\section{Uji Regresi Berganda}

\section{Hasil Uji secara Simultan (Uji F) \\ Tabel 4.6 \\ Uji Simultan (Uji F)}

ANOVA $^{\text {a }}$

\begin{tabular}{|l|r|r|r|l|l|}
\hline Model & \multicolumn{1}{l|}{$\begin{array}{l}\text { Sum of } \\
\text { Squares }\end{array}$} & Df & Mean Square & F & Sig. \\
\hline 1 Regression & 7,610 & 3 & 2,537 & 4,262 &, $009^{\mathrm{b}}$ \\
Residual & 33,928 & 57 &, 595 & & \\
Total & 41,539 & 60 & & & \\
\hline
\end{tabular}

a. Dependent Variable: ROA

b. Predictors: (Constant), LDR, CAR, NPL Sumber : Data Diolah Dengan SPSS

Hasil pengujian uji $\mathrm{F}$ menunjukkan nilai signifikan yang diperoleh adalah 0,009 berarti lebih kecil dari tingkat signifikan 0,05. Karena nilai sig lebih kecil dari 0,05 maka H0 ditolak dan H1 diterima sehingga dapat disimpulkan bahwa CAR, NPL dan LDR secara simultan berpengaruh terhadap variabel ROA.

\section{Hasil Uji secara Parsial (Uji t)}

Tabel 4.7

Uji Parsial (Uji t)

Coefficients $^{\mathrm{a}}$

\begin{tabular}{|c|c|c|c|c|c|}
\hline \multirow[t]{2}{*}{ Model } & Unstandardized Coe & fficients & \begin{tabular}{|l} 
Standardized \\
Coefficients
\end{tabular} & \multirow{2}{*}{$\mathrm{T}$} & \multirow{2}{*}{ Sig. } \\
\hline & B & Std. Error & Beta & & \\
\hline $1 \quad$ (Cons tant) & $-1,014$ & 1,711 & &,- 593 &, 556 \\
\hline CAR & 081 & ,032 &, 304 & 2,532 &, 014 \\
\hline NPL &,- 249 & ,118 &,- 256 & $-2,115$ & 039 \\
\hline LDR &, 021 &, 017 &, 152 & 1,258 & ,214 \\
\hline
\end{tabular}

a. Dependent Variable: ROA Sumber: Data Diolah Dengan SPSS

Hasil pengujian uji t menunjukkan nilai signifikansi untuk setiap variabel independen. Dari hasil pengujian 3 variabel independen dapat diketahui bahwa :

1. CAR mempunyai nilai signifikansi sebesar 0,014 nilai ini lebih kecil dari 0,05 sehingga Ho ditolak, artinya CAR berpengaruh terhadap ROA.

2. NPL mempunyai nilai signifikansi sebesar 0,039 nilai ini lebih kecil dari 0,05 sehingga Ho ditolak, artinya NPL berpengaruh terhadap ROA.

3. LDR mempunyai nilai signifikansi sebesar 0,214 nilai ini lebih besar dari 0,05 sehingga Ho 
diterima, artinya LDR tidak berpengaruh terhadap ROA.

\section{Hasil Uji Koefisiensi Determinasi $\left(\mathbf{R}^{2}\right)$ \\ Tabel 4.8 \\ Model Summary}

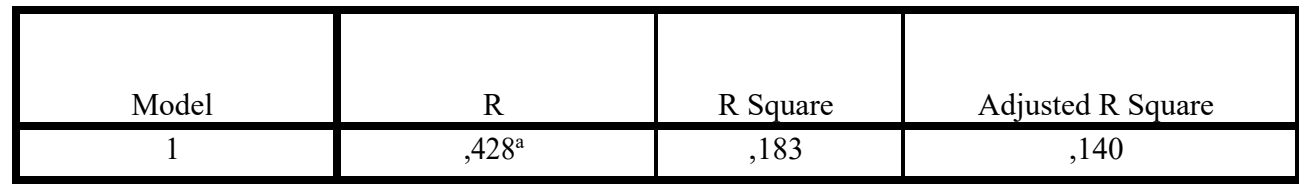

a. $\quad$ Predictors: (Constant), LDR, CAR, NPL

b. Dependent Variable: ROA Sumber: Data Diolah Dengan SPSS

Dari tabel 4.8 diatas menunjukkan bahwa Adjusted R-Square sebesar 0,140. Hal ini menunjukan bahwa sekitar 14\% dari variabel Return On Asset dapat dijelaskan oleh variabel independennya, sementara sisanya $86 \%$ dipengaruhi oleh variabel lain.

\section{Persamaan Regresi}

Tabel 4.9

Persamaan Regresi

Coefficients $^{\mathbf{a}}$

\begin{tabular}{|c|c|c|c|c|c|}
\hline \multirow[b]{2}{*}{ Model } & \multicolumn{2}{|c|}{ Unstandardized Coefficients } & \multirow{2}{*}{\begin{tabular}{|c|}
$\begin{array}{l}\text { Standardized } \\
\text { Coefficients }\end{array}$ \\
Beta
\end{tabular}} & \multirow{2}{*}{$\mathrm{T}$} & \multirow[b]{2}{*}{ Sig. } \\
\hline & $\mathrm{B}$ & Std. Error & & & \\
\hline $1 \quad($ Cons $\tan t)$ & $-1,014$ & 1,711 & &,- 593 &, 556 \\
\hline CAR & 081 & ,032 & ,304 & 2,532 & 014 \\
\hline NPL &,- 249 & ,118 &,- 256 & $-2,115$ &, 039 \\
\hline LDR & ,021 & ,017 & ,152 & 1,258 & 214 \\
\hline
\end{tabular}

a. Dependent Variable: ROA

Sumber: Data Diolah Dengan SPSS

Persamaan Regresi sebagai berikut:

$\mathrm{Y}=\alpha+\beta 1 \mathrm{X}_{1}+\beta 2 \mathrm{X}_{2}+\beta 3 \mathrm{X}_{3}+\mathrm{e}$

$\mathrm{Y}=-1,014+0.081 \mathrm{X}_{1}+\left(-0,249 \mathrm{X}_{2}\right)+0.021 \mathrm{X}_{3}$

Persamaan tersebut mempunyai makna sebagai berikut :

1. Konstanta $=-1,014$

Jika nilai variabel CAR $\left(\mathrm{X}_{1}\right)$, NPL $\left(\mathrm{X}_{2}\right)$, LDR $\left(\mathrm{X}_{3}\right)$ dan dianggap sama dengan nol yang artinya tidak diperhitungkan, maka nilai variabel ROA (Y) mengalami penurunan sebesar -1,014

2. Koefesien $X_{1}=0,081$

Jika nilai variabel CAR $\left(\mathrm{X}_{1}\right)$ mengalami kenaikan sebesar satu satuan, sementara NPL $\left(\mathrm{X}_{2}\right)$, CAR $\left(\mathrm{X}_{3}\right)$ dianggap tetap, maka akan menyebabkan kenaikan nilai variabel ROA (Y) sebesar 0,081

3. Koefesien $\mathrm{X}_{2}=-0,249$

Jika variabel NPL $\left(\mathrm{X}_{2}\right)$ mengalami kenaikan sebesar satu satuan, sementara CAR $\left(\mathrm{X}_{1}\right)$ dan LDR $\left(\mathrm{X}_{3}\right)$ dianggap tetap, maka akan menyebabkan penurunan nilai variabel ROA (Y) sebesar -0.029. 
4. Koefesien $\mathrm{X}_{3}=0.021$

Jika variabel LDR $\left(\mathrm{X}_{3}\right)$ mengalami kenaikan sebesar satu satuan, sementara CAR $\left(\mathrm{X}_{1}\right)$ dan NPL $\left(\mathrm{X}_{2}\right)$ dianggap tetap, maka akan menyebabkan kenaikan nilai variabel ROA (Y) sebesar 0.021

\section{Pembahasan}

Berdasarkan Uji t didapatkan koefisien pengaruh CAR terhadap ROA adalah memiliki tingkat sig $=0,014<0,05$. Ini ditunjukkan bahwa variabel CAR berpengaruh dan signifikan terhadap ROA pada bank konvensional. Hal ini menunjukkan bahwa semakin besar CAR maka semakin tinggi kemampuan permodalan bank dalam menjaga kemungkinan timbulnya risiko kerugian kegiatan usahanya sehingga kinerja bank juga meningkat. Penelitian ini tidak di dukung oleh hasil penelitian yang dilakukan oleh Aminar sutra dewi (2017) dan Erric wijaya, Aulia wahyuning tiyas (2016) yang menunjukkan bahwa CAR tidak berpengaruh terhadap ROA.

Berdasarkan Uji t didapatkan koefisien pengaruh NPL terhadap ROA adalah memiliki tingkat tingkat sig $=0,039<0,05$. Ini ditunjukkan bahwa variabel NPL berpengaruh dan signifikan terhadap ROA pada bank konvensional. Semakin tinggi NPL maka akan semakin buruk kualitas kredit bank yang menyebabkan jumlah kredit bermasalah semakin besar, ini semakin tingkat NPL maka ROA akan semakin rendah dan semakin rendah NPL maka ROA akan semakin meningkat. Penelitian ini tidak di dukung oleh penelitian Daniel nugraha,marjam mangantar, Joy E.Tulang (2019) yang menunjukan bahwa NPL tidak berpengaruh terhadap ROA.

Berdasarkan Uji t didapatkan koefisien pengaruh NPL terhadap ROA adalah memiliki tingkat tingkat sig $=0,214>0,05$. Ini ditunjukkan bahwa variabel LDR tidak berpengaruh signifikan terhadap ROA pada bank konvensional. Hal ini tidak di dukung oleh hasil penelitian yang di lakukan oleh aminar sutra dewi (2017) yang menyatakan LDR berpengaruh terhadap ROA. Semakin tinggi LDR menunjukan semakin baik kondisi likuiditas bank, sebaliknya semakin rendah LDR menunjukan kurangnya efektifias bank dalam menyalurkan kredit.

Kesimpulan dan Saran

Berdasarkan hasil uji secara simultan (UjiF) yang menunjukkan nilai signifikan 0,009 berarti lebih kecil dari tingkat signifikan 0,05 karena nilai signifikan lebih kecil dari 0,05 maka Ho ditolak dan $\mathrm{H}_{1}$ diterima disimpulkan bahwa variabel CAR, NPL, LDR secara simultan berpengaruh terhadap ROA.

CAR berpengaruh terhadap ROA pada Bank Umum Konvensional yang terdaftar di Bursa Efek Indonesia periode 2015-2019, ditunjukkan dalam penelitian berdasarkan hasil uji secara parsial (Uji t) yang menunjukkan nilai signifikansi sebesar 0,014 yang lebih kecil dari 0,05 sehingga Ho ditolak artinya CAR berpengaruh terhadap ROA.

NPL berpengaruh terhadap ROA pada Bank Umum Konvensional yang terdaftar di Bursa Efek Indonesia periode 2015-2019, ditunjukkan dalam penelitian berdasarkan hasil uji secara parsial (Uji t) yang menunjukkan nilai signifikansi sebesar 0,039 nilai ini lebih besar dari 0,05 sehingga Ho diolak.

LDR tidak berpengaruh terhadap ROA pada Bank Umum Konvensional yangterdaftar di Bursa Efek Indonesia periode 2013-2017, ditunjukkan dalam penelitian berdasarkan hasil uji secara parsial (Uji t) yang menunjukkan nilai signifikansi sebesar 0,214 nilai ini lebih besar dari 0,05 sehingga 


\section{Kesimpulan}

CAR,NPL, dan LDR secara simultan menunjukkan nilai signifikan 0,009 berarti lebih kecil dari tingkat signifikan 0,05 karena nilai signifikan lebih kecil dari 0,05 maka Ho ditolak dan $\mathrm{H}_{1}$ diterima disimpulkan bahwa variabel CAR, NPL, LDR secara simultan berpengaruh terhadap ROA. Berdasarkan hasil uji secara parsial (Uji t).

- CAR menunjukkan nilai signifikansi sebesar 0,014 yang lebih kecil dari 0,05 sehingga Ho ditolak artinya CAR berpengaruh terhadap ROA.

- NPL mempunyai nilai signifikansi sebesar 0,039 nilai ini lebih kecil dari 0,05 sehingga Ho ditolak, artinya NPL berpengaruh terhadap ROA.

- LDR mempunyai nilai signifikansi sebesar 0,214 nilai ini lebih besar dari0,05 sehingga Ho diterima, artinya LDR tidak berpengaruh terhadap ROA.

\section{Saran}

Penelitian yang akan datang sebaiknya memperpanjang periode penelitian atau memperbanyak jumlah sample agar hasil yang diperoleh dapat lebih merefleksikan pergerakan ROA serta mempertimbangkan aktor - faktor lain yang dapat mempengaruhi ROA di Bursa Efek Indonesia secara historikal.

\section{DAFTAR PUSTAKA}

Anwar, Sanusi. 2016. Metodologi Penelitian Bisnis. Cetakan Keenam. Jakarta: Salemba Empat

Bank Indonesia.2011. Peraturan Bank Indonesia Nomor 13/1/PBI/2011 tanggal 5 Januari 2011 tentang Penilaian Tingkat Kesehatan Bank Umum.Jakarta.

Bank Indonesia. 1998. UU No.10 tahun 1998, Tentang Perbankan

Dewi, AS. 2017. " Pengaruh CAR, BOPO,NPL,NIM, dan LDR terhadap ROA pada perusahaan di sektor perbankan yang terdaftar di BEI periode 2012- 2016." Jurnal Sekolah Tinggi Ilmu Ekonomi KBPF, Vol.01,No.03, hlm. 223-236.

Fahmi, Irham. 2013. Analisis Laporan Keuangan. Bandung: Alfabeta. Fahmi,

Irham. 2015. Pengantar Manajemen Keuangan Teori dan Soal Jawab.

Bandung: Alfabeta.

Ghozali, Imam.2016. Aplikasi Analisis Multivariate dengan Program SPSS, Semarang: Badan Penerbit Universitas Dipenogoro.

Hamidah, 2018. Manajemen Keuangan Teori, Bogor :Mitra Wacana Media Harahap,

Sofyan Syafri. (2015). Teori Kritis Laporan Keuangan. Jakarta : PT Raja Grafindo Persada.

Kasmir, (2014). Bank dan Lembaga Keuangan Lainnya. Edisi Revisi 2014. Jakarta: Raja Grafindo Persada

Kasmir. (2016). Analisis Laporan Keuangan. Jakarta: Rajawali Pers. Margaretha,

Farah. (2014). Dasar-dasar Manajemen Keuangan. Jakarta: Dian Rakyat

Musthafa. (2017). Manajemen Keuangan. Yogyakarta: CV. Andi Offset.

Nugroho, Daniel, Marjam Mangantar dan Joy E. Tulung (2019). "Pengaruh CAR, BOPO, NIM, dan NPL terhadap ROA industri bank umum swasta nasional buku 3 periode 2014-2018." Jurnal EMBA Vol.7,No.3, Hlm.4222-4229

S. Munawir. 2014. Analisis Laporan Keuangan. Yogyakarta : Liberty

Sugiyono. (2017). Metode Penelitian Kuantitatif, Kualitatif, dan R\&D. Bandung : Alfabeta, CV.

Sutrisno. 2012. Manajemen Keuangan Teori, Konsep dan Aplikasi. Yogyakarta: EKONISIA.

Wulandari, Fitria (2015). Faktor-FaktorYang Mempengaruhi Penyaluran Kredit pada Bank Umum yang Telah Go Public Periode Tahun 2011-201. Semarang: Jurusan Akuntansi Fakultas Ekonomi Dan Bisnis Universitas Dian Nuswantoro Semarang. 